\title{
Students' Perception on Teaching Minimalist Syntax (A Descriptive Analytic Study at One University in Karawang)
}

\author{
Kelik Wachyudi \\ University of SingaperbangsaKarawang \\ Karawang, Indonesia \\ Kelik.wachyudi@staff.unsika.ac.id
}

\begin{abstract}
In this research paper has a goal to explicate students' perception on teaching English minimalist syntax theory. Thus, students enable to scrutinize simple sentencces by drawing tree diagram as manually or used online syntax tree generator in my interactional classroom by using of minimalist syntax theory. To obtain the data, I used depth interview to students with GPA A - GPA C as my respondents. So that, I acquired of students' perception of teaching English syntax as comprehensively. As far of my concern on finding and discussion, I got that students with GPA A did not meet any challenges to draw the tree diagram as manually or used online generator; Students with GPA B divided into two responses; any students told that they have a great effort to draw the sentence by using minimalist syntax and part of others told that this theory is a new for them but they were able to draw the sentence by using ofthis approaches; for the last, students with GPA C, all of them coincided that they need a great dial of effort to draw the sentences by using minimalist syntax theory.
\end{abstract}

Keywords-minimalist syntax; students; perception; teaching; syntax.

\section{INTRODUCTION}

Knowledge of syntax has an essential for English language learners. Syntax is element of lingusitics which is concerns on sentence. The sentence is approached by using minimalist syntax. Zwart (1997) thinks that minimalist programme is how to linking between sound and meaning. Moreover,Kadarisman (2009) minimalist programme leads to decriptive adequacy \& explanation adequac. The properties of minimalist syntax are still completely not understood by most of tertiary students. In the former, the students unfamiliar to this method in analyzing sentence based on linguistic perspective. After they learn on this subject they understand about this method. On the contrary, as far as I am concerning to this subject of teaching, there is still rare study about minimalist syntax in English undergraduate students in Indonesia. By considering of my viewing, there arise some questions? Is teaching syntax in English education department at under- graduate level so important for students? Is it better to teaching English syntax by using minimalist approach to tertiary student at undergraduate level in English education department? Is it useful to teaching English syntax by using minimalist approach to tertiary student at undergraduate level in English education department? Is it useful to teaching English syntax by using generative tool online for tertiary students at English language department? These are questions that have been disturbing of my mind. Therefore, to find the answers, I conduct of this research at one university in Karawang.

\section{METHODS}

To collect the data, I used interview as part of qualitative approach with embracing descriptive as my method. My statement pursue to Alwasilah (2006) where said that qualitative approach is used because the type of this research is natural setting. For my informant 15 students at four th semester from English department in one university in Karawang. My resources data, I took from nonnative English language learners. My primary instrument is my self as the researcher. The other instrument is note taking to write students' perception duering interview.

Moreover, I used in depth interview to 15 students: 5 students who got score more than 81 (A), 5 students who got score more than 66 (B); and 5 students who got score in range 55-65 (c). My population was 85 students in three classes and my sample is 15 students from three classes. At last, I explicated of my students' perception on this reseacrh paper around teaching English syntaxt through minimalist approach. 


\section{RESULT AND DISCUSSION}

\section{Result.}

In this section, I divided into three categorization of students' perception based on their result after they passed the final examination. The three categorization were, first, the students with score more than 81 (A); second, the students with score more than $66(\mathrm{~B})$; third, the students with score in range 55-65 (c). Based on this findings, I offered 7 questions to each students.

\section{Discussion}

In this section, I explicated 7 questions to all my respondents. First, Is syntax essential for you? All students who got score with range in between 55 untill 85 said that syntax is important because in syntax, they had different strategy to analyze sentence. Second, Do you know what the minimalist approach is? Based on your explanation, syntax is part of structure and it could be analyzed by generated the sentence or phrase. Third, Ismorphosyntax challenging for you in analyzing sentence? I had different type of answer from my students; 1) The students got more than 81 said it was not difficult because it was interesting way to analyse sentence with tree syntax; 2) The students got more than 65 were divided into two different responses; 3 students said that the way of analyzing by using minimalist syntax was not difficult and others said it was challenging but they were able to analyze the sentence by using generative syntax alhough they were taking more time. Third, What the most challenging items in analyzing syntax by using minimalist approach? All students said that determiner phrase as the most challenging because they already knew that determiner as head. In common, as contrary to former explanation that they knew that noun phrase as a head. Fourth, Is it useful for you as foreign language learner to learn syntax with minimalism approach? There were two type of students' perception; 1) Students who got score in range 66-85 said that minimalist approach is useful because the knew about surface structure and deep structur; 2) the students in range 55-65 divided into two perceptions, three from 5 students said it is useful because this approaches help from doing wrong and other said it was not useful because, in fact, syntax could not implemented in school level. Fifth, Is it wasting of your time to draw the tree by using minimalist syntax? All of my students said it was not waste of their time to draw the sentence by using generative syntax by minimalis approach. Sixth, Ishelful for all of you when I suggested you to used generative tool online from (Shang)? All my students said it was helpfull for them because they could learn individually by using their smartphone or their desktop. 7) Do you agree if syntax deleted from our curricula? All my students said I think we must know how to create the structure properly at first such in syntax. Therefore, they taught, they disagree if syntax deleted in English curricullum.

\section{CONCLUSION}

In my conclusion, I conclude that learning English syntax with minimalis approach is not a big challenging for students as far as the teacher demonstrated the way analyzing the sentence by using minimalist approach. Moreover, I achieved that students think minimalist syntax is useful and essential for them to learn how to analyze grammar by generative perspective. As my final result, I got that using generative syntax online from Shang was helpful to my students in analyzing sentence. Therefore, teaching English syntax by using minimalist approach is needed because they are able to recognize surface structure and deep structure.

\section{References}

[1] Alwasilah, A., Chaedar. (2006). Pokoknyakualitatif; Aasardasarmerancangdanmelakukankualitatif. Jakarta: PT Pustaka Jaya.

[2] Jart., W. J. (1998). The minimalist program. J. Linguistics 34 (1998), 213-226. Printed in the United Kingdom.Cambridge University press.

[3] Kadarisman, A. E. (2009). Keterbatasanteoriminimalis Chomsky.KaryaDosenFakultasSastra UM. 